\title{
Strategic Analysis of Sino-Foreign Higher Education Cooperative Universities Based on SWOT Model
}

\author{
Qingze Wang \\ Xi 'an Jiaotong-Liverpool University, IBSS, Suzhou Jiangsu Province, 215028, China \\ ${ }^{*}$ Corresponding author. Email: gaoming@cas-harbour.org
}

\begin{abstract}
As the internationalisation of education around the world continues to advance, cross-border cooperation between institutions is rapid, especially in the domain of higher education. As a Significant part of China's educational undertaking, Chinese-foreign cooperative education, while developing an abundance of practical international talent, has also promoted the reform and prosperity of higher education, covering various fields of economic and social construction. In this paper, a SWOT analysis of S (Strengths) W (Weaknesses) O (Opportunities) T (Threats) is conducted on the Sino-foreign higher education cooperation model. The results show that the development of Sino-foreign cooperative universities has great advantages and prospects, but the opportunities also bring the fact of fierce competition from universities of the same nature. In response to the unsatisfactory enrolment situation in 2020 , strategies related to sustainable development are proposed. The enrolment aspect needs to be reasonably advertised to highlight the university's strengths; the university needs to clarify its positioning, improve the quality of teaching and increase its research output in order to improve their social status in the country.
\end{abstract}

Keywords: Sino-foreign cooperative education, SWOT model, Admissions

\section{INTRODUCTION}

Economic globalization has become an unstoppable development trend in the world, and the globalization of education is booming along with it [1]. The wave of study abroad is a prominent manifestation of the globalisation of education, which is mainly manifested in the movement from developing countries to developed countries [2]. This is due to the fact that developed countries have richer educational resources, more mature education systems, longer educational traditions and more advanced teaching and management methods. The WTO has included higher education in the General Agreement on Trade in Services (GATS) and it has become an important component of trade in services. China has joined the WTO in 2001 and is gradually integrating into the wider world economy [3].

In September 2003, the state promulgated new regulations to encourage Chinese-foreign cooperative schools to introduce high-quality foreign educational resources and increase the number of advanced international curricula and teaching materials that are urgently needed in China [4]. With the further development of internationalisation of education, a new model of education has emerged, that is, the development of international co-operative education. By bringing in resources from foreign universities and establishing cooperative institutions or programme with domestic universities, for example, in some courses or majors.

As the market economy flourishes and becomes more widespread, the concept of economisation has been applied to the field of education. The economisation of education refers to the adjustment of educational behaviour to market demand in order to achieve high efficiency and quality development of education and maximise economic benefits [5]. The study of the past literature reveals that research on education marketing, especially the marketing strategies of Sino-foreign cooperative education, is just at the beginning stage.

In addition, there are risks and immaturity, such as students' lack of understanding of Chinese-foreign cooperative education, higher tuition fees than ordinary higher education, and educators' neglect of management [6]. How to stand firm in the fierce market competition and what advantages and characteristics the school sponsoring unit has to attract students will be the core issue for the sustainability of Chinese-foreign 
cooperative institutions. This paper analyses its strengths, weaknesses, opportunities and threats, and attempts to create a scientific and reasonable marketing strategy for such universities to obtain quality students so as to solve the problem of survival and development of universities.

\section{LITERATURE REVIEW}

The globalisation of education is an international development direction, and the transnational pattern and mobility of higher education is an irresistible trend [7]. The development of Sino-foreign cooperation in higher education is a trend in social development and an essential means of achieving internationalization in education. Both at home and abroad, international co-operative education in higher education has shown various degrees of rapid development, which has also attracted the attention of various institutions and scholars at home and abroad. At present, there are a lot of research on the mode of co-operative schooling in higher education, which can be summarized into the following aspects.

The first is about the evaluation of the teaching quality aspect of Sino-foreign cooperative education. The quality of teaching and learning in Chinese-foreign cooperative education is the lifeline as far as higher education is concerned, which is of great concern to all stakeholders [8]. Lin (2016) [9] shows that the basic relationship between the scale, quality and effectiveness of Chinese-foreign cooperative education should be: with moderate scale as the basis, quality of innovation as the key, and growth in efficiency as the goal, which is fundamental to the sustainable development of Sino-foreign cooperative education. To achieve a stable position, it is necessary to actively recognise and adjust to the new international norm of the current situation and to the new stage in the evolution of the teaching system. Fan et al. (2018) [10] explored the teaching strategies and made corresponding suggestions: strictly control the system of Chinese-foreign cooperative schools, follow up foreign teaching methods and excellent management models, and strengthen immersion in English learning.

Secondly, it explores how to develop Chinese-foreign cooperative education. Throughout China, research on Chinese-foreign cooperative education mostly focuses on the analysis of higher education institutions, which is due to its obvious problems and defects, such as a certain blindness and arbitrariness in project development, over-emphasis on economic benefits, and insufficient investment in teachers and hardware [11]. However, many scholars have also overlooked the serious problems exposed in higher education co-operative education. Therefore, this paper aims to fill this gap that is missing in the study of universities.
Thirdly, one category is a case study of a Chinese-foreign cooperative university. Daniela (2017) [12] identifies the performance and quality of activities carried out by pre-university education institutions through a SWOT analysis, outlining the performance of modern systems needed to implement strategies and decision management. Peng et al. (2020) [13] used a SWOT analysis to conduct an in-depth analysis of online foreign language teaching at Kerry University as an example. With the increasing number of overseas campuses around the world, competition is becoming fierce. One of the main reasons for the closure of many overseas campuses is the lack of a sufficient number of quality students. Currently, the recruitment problem has become a thorny issue for universities around the world in the process of opening overseas campuses [14]. Gao and Liu (2020) [15] propose a strategy that pays attention to a detailed analysis of the social environment of the country of introduction and, on this basis, determines the positioning of the target students for admission, which is conducive to improving the position of the country and the university in the global landscape.

\section{ANALYSIS}

\subsection{Basic Information}

Overseas universities began experimenting with Chinese universities as early as the 1980s. Due to the shortage of domestic higher education supply, it also opened channels for foreign universities to enter the Chinese education market. Starting from the early 1990s, the Ministry of Education promulgated a series of regulations and policies that facilitated the development of Sino-foreign cooperative education from accidental and disorderly to systematic and formal. According to data released by the Education Information Platform for the Regulation of Chinese-Foreign Cooperative Education[16], as of December 2019, there were more than 2,400 schools and programmes offering Chinese-foreign cooperative education, with 1,147 years of undergraduate education or higher. Table 1 shows the most recognisable higher education institutions in China, with the University of Liverpool at WJU standing out in terms of enrolment among the many schools created during the same period.

In China, depending on the nature of the Chinese-foreign cooperative institutions, they are divided into independent institutions with legal personality, such as XJTLU and Shanghai New York University. However, most Chinese-foreign cooperative institutions currently do not have legal personality and are non-independently configured institutions. Regardless of whether they have legal personality, Sino-foreign cooperative schools should fully explore and gather high-quality educational resources from 
various countries or regions, achieve the integration of obtain the dominant power in school operation. multiple cultures, reduce the risk of cooperation and

Table 1. List of Chinese-foreign cooperatively-run schools having entity nature.

\begin{tabular}{|c|c|c|c|c|}
\hline Institution name & Domestic partner & Foreign cooperative party & $\begin{array}{c}\text { Recruit } \\
\text { students } \\
\text { number } \\
(2020)\end{array}$ & $\begin{array}{l}\text { Approval } \\
\text { date }\end{array}$ \\
\hline XJTLU & Xi 'an Jiaotong University & University of Liverpool & 4202 & 2006 \\
\hline $\begin{array}{c}\text { University of } \\
\text { Nottingham Ningbo }\end{array}$ & Zhejiang Wanli Group & $\begin{array}{l}\text { University of } \\
\text { Nottingham }\end{array}$ & 1766 & 2005 \\
\hline $\begin{array}{c}\text { Beijing Normal University } \\
\text { - Hong Kong Baptist } \\
\text { University }\end{array}$ & Beijing Normal University & $\begin{array}{c}\text { Hong Kong Baptist } \\
\text { University }\end{array}$ & 1881 & 2005 \\
\hline $\begin{array}{c}\text { Chinese University of } \\
\text { Hong Kong } \\
\text { (Shenzhen) }\end{array}$ & Shenzhen university & $\begin{array}{c}\text { The Chinese University } \\
\text { of Hong Kong }\end{array}$ & 1360 & 2014 \\
\hline $\begin{array}{c}\text { Wenzhou Kean } \\
\text { University }\end{array}$ & Wenzhou university & Ken university & 1000 & 2014 \\
\hline $\begin{array}{l}\text { Guangdong Israel } \\
\text { Institute of } \\
\text { Technology }\end{array}$ & Shantou university & $\begin{array}{l}\text { Israel Institute of } \\
\text { Technology }\end{array}$ & 280 & 2017 \\
\hline $\begin{array}{c}\text { Duke Kunshan } \\
\text { University }\end{array}$ & Wuhan university & Duke university & 235 & 2018 \\
\hline $\begin{array}{c}\text { New York University } \\
\text { Shanghai }\end{array}$ & $\begin{array}{c}\text { East China Normal } \\
\text { University }\end{array}$ & New York university & 251 & 2012 \\
\hline
\end{tabular}

\subsection{SWOT Analysis}

\subsubsection{Strength}

A Sino-foreign cooperative university can save costs, improve the quality of learning and enrich cultural life. According to statistics, through the ' $\mathrm{X}+\mathrm{Y}$ ' cooperation model, students can save about $£ 20,000$ in study fees [17]. Meanwhile, students who choose to study directly abroad may be emotionally uncomfortable when faced with higher education abroad and will need a delay to adjust compared to the full English education environment of a Sino-foreign cooperative university. As a result, students who have a Sino-foreign cooperative university study may have a greater ability to adapt in terms of further study abroad. Moreover, according to the 2020 Undergraduate Progression
Quality Report[18], the average progression rate of top universities in China is $50 \%$, while Table 2 shows the results of the undergraduate progression rate survey of Sino-foreign cooperative universities. The top-ranked Tsinghua University has an overall progression rate of $76.3 \%$, and in comparison, graduates from these types of Sino-foreign cooperative schools have higher progression rates. Higher academic standards can benefit individuals for life, and have a higher progression rate is an advantage that attracts high school graduates. The ongoing need for support and progression of student academic achievement is an issue of major concern to the higher education sector, students and practitioners [19]. Figure 1 shows the progression rate at XJTLU, which also shows that the rate is increasing year on year.

Table 2. Quality of progression to employment in key schools.

\begin{tabular}{cc}
\hline Institution name & Quality of further education and employment \\
\hline Xi 'an Jiaotong-Liverpool University & QS TOP10: $38.1 \%$ \\
& TOP100:80.36\% \\
\hline
\end{tabular}




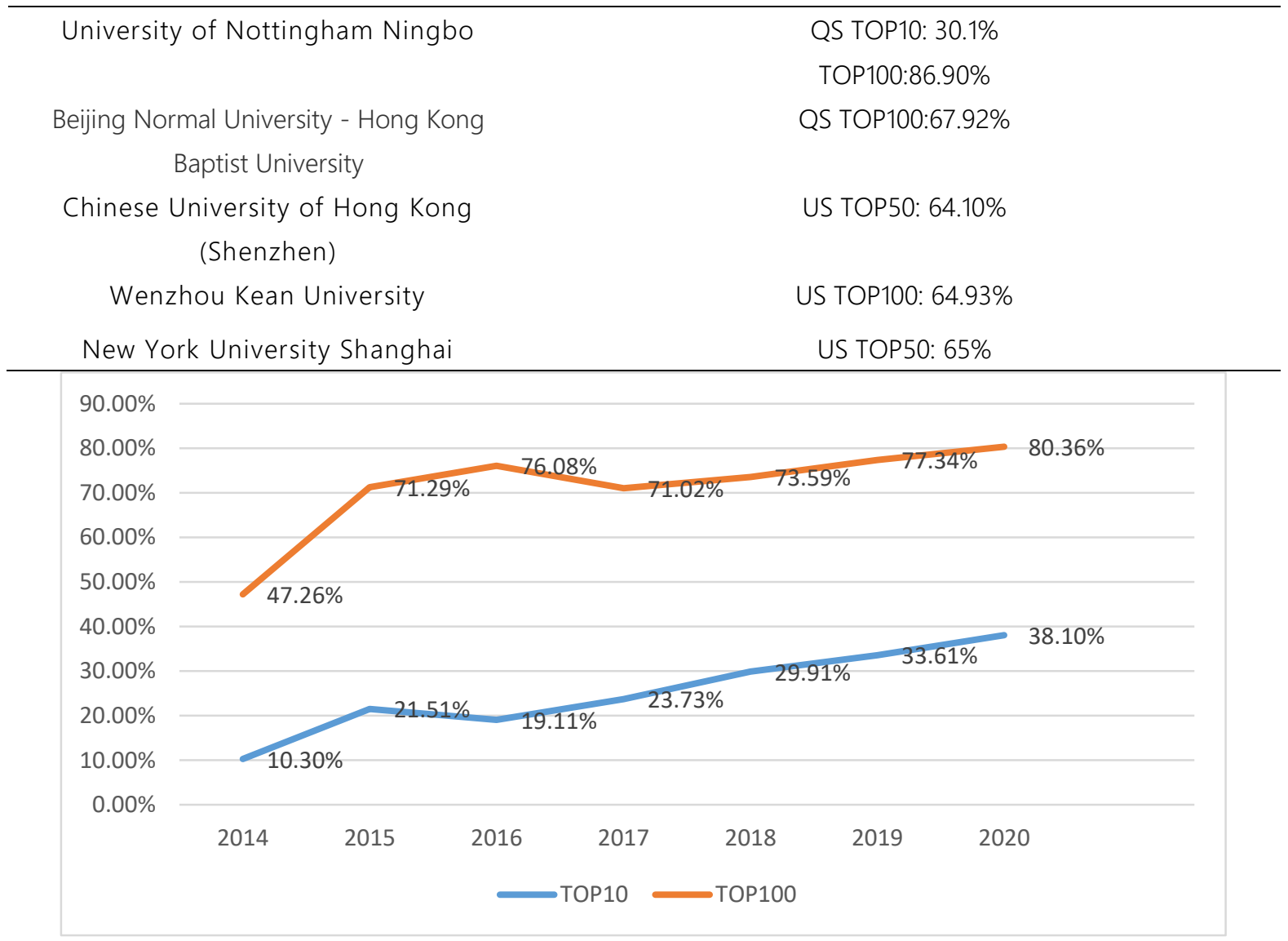

Figure 1. The quality of admission of XJTLU in recent years (based on QS world rankings)

\subsubsection{Weakness}

Co-operative schools generally use a certain number of original foreign textbooks and employ foreign teachers to teach foreign languages, which undoubtedly places a higher demand on students' foreign language skills. Many middle-class parents feel that the high cost of studying at a Sino-foreign cooperative university lacks justification compared to the low cost of domestic university. These schools also suffered a huge loss of educational resources as a result of the COVID-19 outbreak, and the lack of preparation for unexpected situations in the short period of its existence was an important weakness. Many experienced expatriate tutors resigned during this period because of the online teaching [20].

\subsubsection{Opportunity}

The State promotes a policy of encouraging co-operative schooling. Sino-foreign cooperative education enjoys the preferential policies stipulated by the state, while introducing quality education resources from abroad. Co-operative education enables students to experience the high-quality educational resources of foreign countries and obtain the same degree certificates as foreign students right in China. As China's economy develops rapidly, there has been a great improvement in people's standard of living. Therefore more and more students are choosing to study abroad. University students who are receiving higher education at home are also eager to be trained in the foreign education model and education system of foreign countries at the same time.

\subsubsection{Threat}

As thousands of Sino-foreign cooperative schools have sprung up, it is difficult to stand out from the same educational model. Likewise, this new style of culture is an impact on traditional education in China, which is mixed with the collision of Western values and traditional culture.

\section{DISCUSSION AND RECOMMENDATION}

According to the analysis, with the trend of studying abroad and the strong support of the state, the enrollment situation of Sino-foreign cooperative universities in 2020 is not ideal, and the quality of students is declining. As shown in Figure 2, taking XJTLU as an example, the admission marks above the first-class line, suddenly dropped in 2020. As shown in Figure 3, the score of Shandong Province, one of the most competitive provinces, also dropped sharply. The 
following paragraphs will analyse the reasons for this situation.

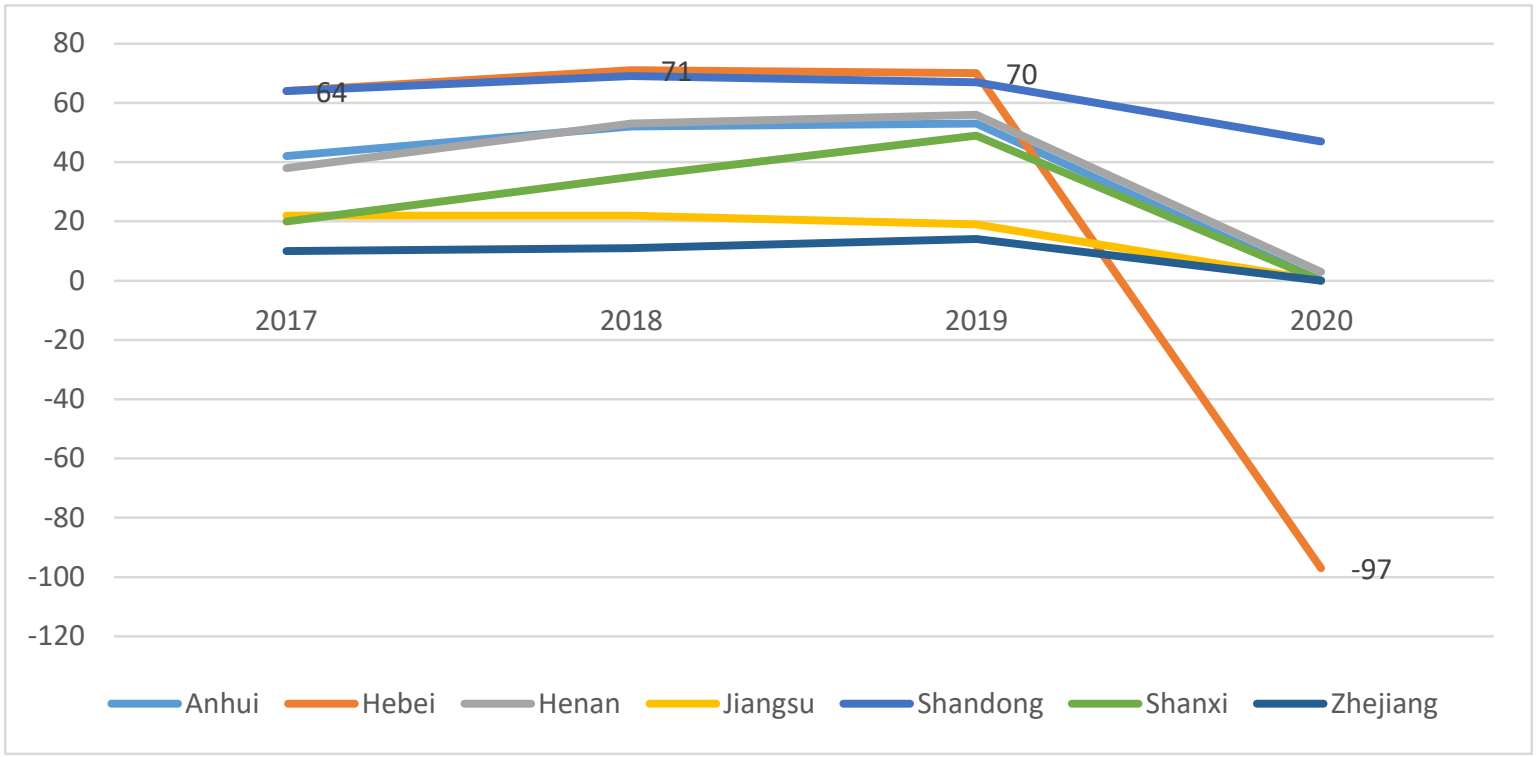

Figure 2. XJTLU changes the score of science admission in each province when the score exceeds the first score.

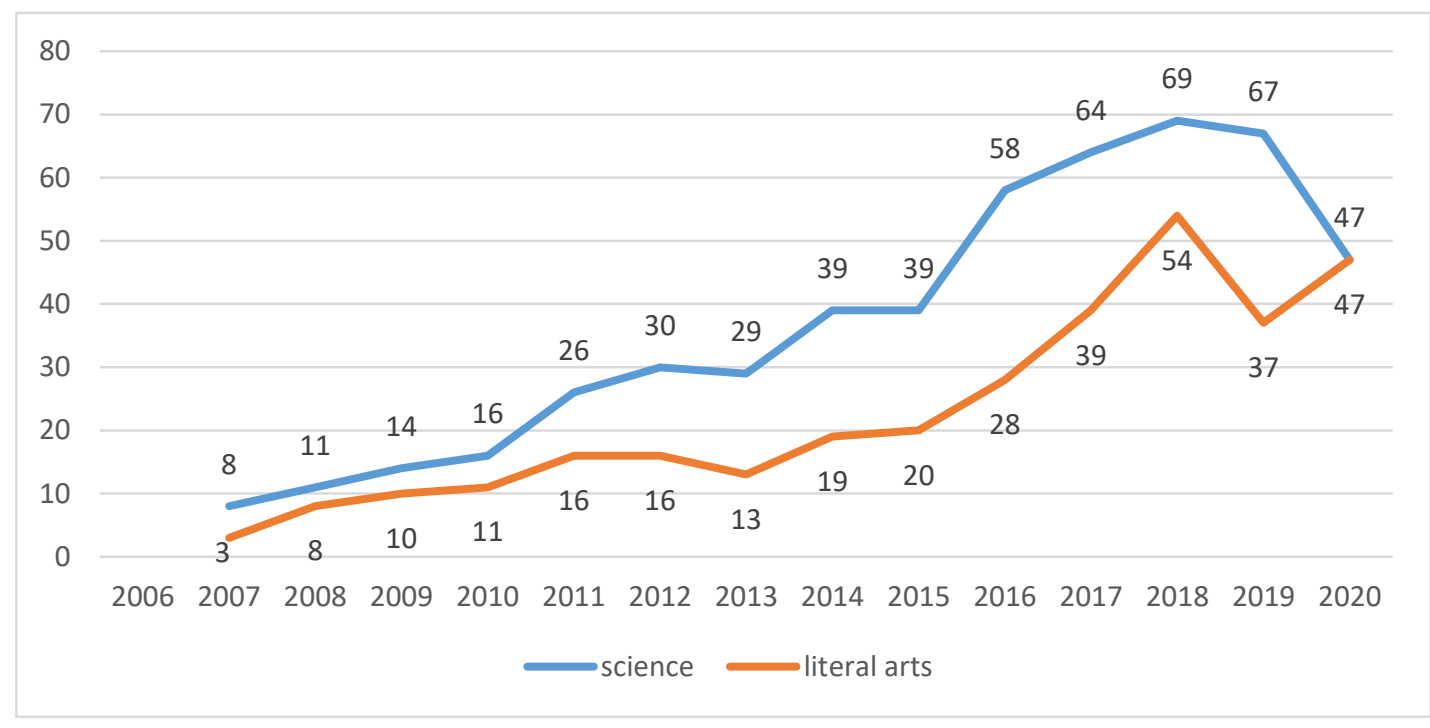

Figure 3. XJTLU in Shandong Province admission score line respectively in the arts and science over a line score.

\subsection{Impact of the COVID-19 epidemic}

In terms of the globalisation of the epidemic, overseas epidemic peaks in July 2020, which is also the time when domestic university students fill out their voluntary applications. Parents' health concerns have led to fewer people being willing to go abroad, thus concerns about Sino-foreign cooperation have increased. The vast majority of Chinese-foreign cooperative studies are more or less associated with studying abroad intermediary associations, which is a 'systemic risk'. But if, after rational reflection, the international epidemic is well contained over the next two years, the impact of the first cohort of study abroad in 2023 will be minimal, and the reasonable spread of ' $2+2$ ' study abroad model illustrates and prompts the ' $4+0$ ' option of autonomy, this situation will not get worse. Hence, it is not only the sudden change in the general social environment that has led to this, but the admissions office needs to take responsibility for the lack of publicity.

\subsection{Changes in international trend}

China's economic development has also led to the development of education. In the latest 2022 QS (Quacquarelli Symonds) rankings, domestic schools have made great progress. Relying on foreign help, Sino-foreign cooperative universities do not work hard and research results are scarce, hence the devaluation of their diplomas. While the international situation is a chronic change, this requires the Chinese and foreign partner universities to improve the quality of their 
teaching and increase their research output in order to improve their social status in the country.

\subsection{Fierce Competition}

With the rise of Chinese-foreign cooperative schools, there is a serious mutual devaluation in schools, which is not managed effectively. Every school wants to have the best students and this is a source of conflict. It is envisaged that a joint organisation of schools promoting each other and competing peacefully would not only inform the public about such universities of a Sino-foreign cooperative nature, but would also broaden the scope of publicity.

\subsection{Unclear self-positioning}

The general enrolment of Sino-foreign co-operative schools is aimed at key secondary schools in developed provinces, and there are bound to be loopholes in the publicity based on specific groups of people. Moreover, the demand becomes rigid when most of the students who apply are well prepared and have a strong will to apply. For long-term development, it is important to clearly position the school, pay attention to evaluation and control the scale, which is an important guarantee for the school to improve quality and develop its characteristics.

\section{CONCLUSION}

The vigorous development of Chinese-foreign higher education co-operative education has cultivated a large number of talents while attracting the inflow of many foreign talents and reducing the loss of domestic talents at the same time. Through a SWOT analysis of the sino-foreign cooperative education model, this paper shows that sino-foreign cooperative education has broad development prospects, the advantages of innovative learning models and full English teaching, as well as the opportunities for national support and development in the new era. However, under the influence of covid-19, how to deal with the weakness of the existing loss of excellent teacher resources and the threat of too many universities of the same nature competing with each other to seek a smooth development is also a problem that needs to be solved. Establishing a multi-university joint organisation, carrying out multi-directional, multi-faceted and factual enrolment promotion, rational competition, building a diversified platform for humanistic exchanges and a good international atmosphere, clarifying the positioning of the university, improving teaching quality and optimising educational resources can effectively address the direction and problems of the future sustainable development of Sino-foreign cooperative universities.

\section{REFERENCES}

[1] Spring, J. Globalization of Education: An Introduction. New York: Routledge (Sociocultural, Political, and Historical Studies in Education). 2014. Available at: https://search.ebscohost.com/login.aspx?direct=true $\& \mathrm{db}=$ edsebk\&AN=821602\&site $=$ eds-live $\&$ scope $=$ site (Accessed: 10 July 2021).

[2] Mitić, S. and Mojić, D. Student choice of higher education institutions in a post-transitional country: evidence from Serbia, Economic Research-Ekonomska Istrazivanja, 2020, 33(1): 3509-3527.

[3] Lai, B. The Challenges to China's Higher Education Administration Presented by Entry into the WTO and Possible Countermeasures, Chinese Education \& Society, 2003, 36(5): 60-68.

[4] Zhou, X. et al. Constructing a Quality Control System for Personnel Training in Sino-foreign Cooperative Education:A Case Study of GDUT Sino-foreign Cooperative Education Project, Journal of Guangdong University of Technology(Social Sciences Edition), 2020, 20(2):106-112.

[5] Klyov, M. V. and Popov, V. O. (2015) The expansion of the education market and economization of education system: sociological analysis, Granì, 2015, 18, 1(117):99-103.

[6] Sun, K. Analysis on the risk management mechanism of Sino-foreign cooperative universities, Journal of National Academy of Education Administration, 2013(2):59-64.

[7] Forstorp, P.-A. and Mellström, U. (2018) Higher Education, Globalization and Eduscapes. [electronic resource]: Towards a Critical Anthropology of a Global Knowledge Society. 1st ed. 2018. Palgrave Macmillan UK (Palgrave Studies in Global Higher Education). Available at: https://search.ebscohost.com/login.aspx?direct=true $\& \mathrm{db}=\mathrm{cat} 07934 \mathrm{a} \& \mathrm{AN}=x \mathrm{j} 1.9781137440471 \&$ site $=\mathrm{ed}$ s-live \&scope $=$ site (Accessed: 11 July 2021).

[8] Wang, L., et al. Quality Promoting Strategies for Sino-foreign Cooperative Education in Higher Education in Tianjin, China Education of Light Industry, 2016(5): 12-15.

[9] Lin, J. Basic Relationships Among Scale, Quality, and Benefits in Sino-Foreign Cooperative Education, Chinese Education \& Society, 2016, 49(4/5): 254-270.

[10] Fan, Z., et al. Situations and Strategies of Sino-Foreign Cooperative Education in 
Information Explosion Age, Journal of Southwest China Normal University(Natural Science Edition), 2018, 43(7):169-175.

[11] Zou, Y., et al. Exploration and Practice of Diagnosis and Continuous Improvement of Education Quality of Sino - foreign Cooperative Education Project of Higher Vocational Colleges, Journal of Yantai Vocational College, 2017, 23(4):9-12.

[12] Daniela, V. The SWOT Analysis of Pre-university Education, Ovidius University Annals, Series Economic Sciences, 2017, 17(1): 601-605.

[13] Peng, S. et al. SWOT Analysis of Foreign Language Teaching Online under the Background of the"COVID-19 Epidemic:A Case Study of Kaili University', Journal of Kaili University, 2020, 38(2):81-85.

[14] Zou, J. and Wang, L.A. Study on the recruitment strategy of Australian overseas branch campuses: a case study of Monash University in Malaysia and Wollongong University in Dubai, Comparative Education Review, 2020, 42(1):089-096.

[15] Gao, Y. and Liu, J. International student recruitment campaign: experiences of selected flagship universities in China, Higher Education: The International Journal of Higher Education Research, 2020, 80(4):663.

[16] Education Information Platform for the Regulation of Chinese-Foreign Cooperative Education, 2019.

[17] Deng, R. The Statistics and SWOT Analysis of Chinese- foreign Cooperation of School Running in Higher Education in China', Academy, 2012(3):77-81.

[18] Undergraduate Progression Quality Report, 2020.

[19] Gamble, R. 'Exploring the factors which influence and support the development of academic growth in Higher Education. 2019.

[20] Lou, Y. and Chen, J. The Current Situation and Countermeasures of Online Speaking Teaching for Foreign Teachers in Higher Education Institutions, Data of Culture and Education, 2020(22):223-236. 